\title{
Measuring Disparities in Cost and Spending across Connecticut School Districts
}

By Bo Zhao and Nicholas Chiumenti

\section{RESEARCH REPORT 20-2}

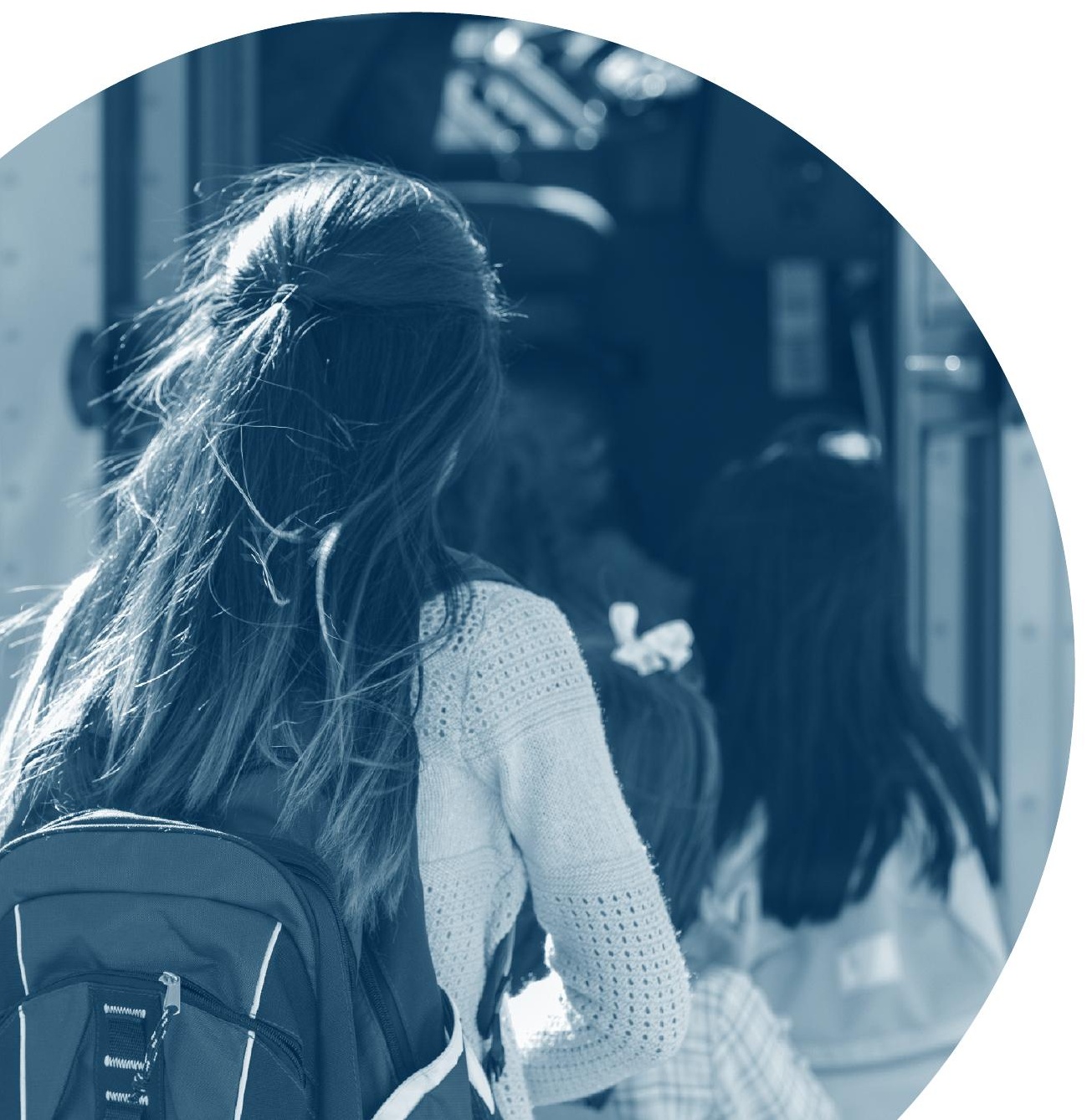




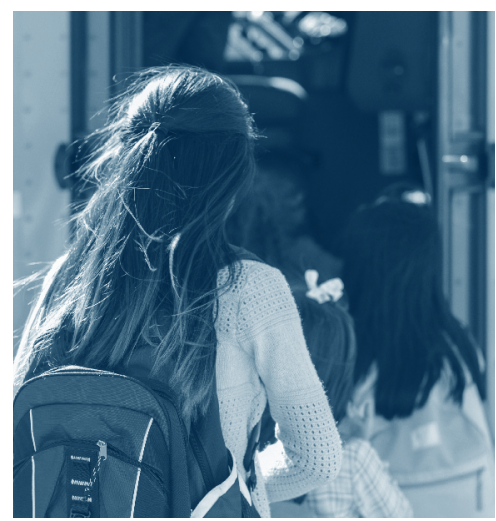

\section{New England Public Policy Center}

www.bostonfed.org/neppc

\section{Staff}

Katharine Bradbury Mary Burke Nicholas Chiumenti Melissa Gentry Lan $\mathrm{Ha}$ Osborne Jackson Morgan Klaeser Samuel Makikalli Bojana Rasic Darcy Saas Riley Sullivan Jeffrey Thompson Thu Tran Bo Zhao

\section{Table of Contents}

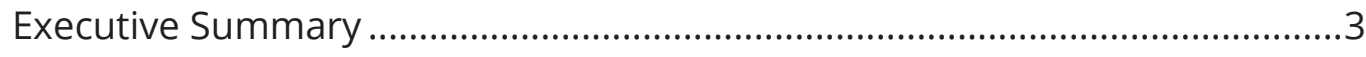

I. Introduction

II. Background of Connecticut's Education Finance System .............................

III. Measuring Cost Disparities .......................................................................

IV. Evaluating Equity and Adequacy in School Spending............................... 12

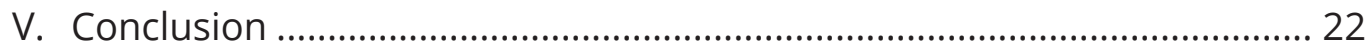

The views expressed in this report are those of the authors and do not necessarily represent positions of the Federal Reserve Bank of Boston or the Federal Reserve System. 


\section{EXECUTIVE SUMMARY}

Despite multiple court cases and repeated efforts at reform, there are still significant concerns about the equity and the adequacy in Connecticut's public K-12 education funding. One vital component of any attempt to reform education finance is a methodologically rigorous evaluation of what it would cost school districts across the state to achieve target performance standards given their student characteristics.

This report addresses that need, evaluating the equity and the adequacy of school spending in Connecticut based on education costs. Different from actual school expenditure, a district's education cost is an estimation based on its cost factors that are outside the direct control of local officials at any given point in time; efficiency levels are held constant across school districts in the estimation. This report finds large disparities in education costs due to differences among school districts in cost factors. It also finds that, despite existing state aid programs, disparities in cost-adjusted spending across the state remain large. Spending in some districts is well below the levels needed to achieve common performance goals.

Among the specific findings of this report is that in the last year for which data were analyzed, the average costs of school districts with the lowest socioeconomic status and highest level of student need were 62 percent greater than those of districts with the highest socioeconomic status and the lowest level of student need. When this report holds every district's efficiency at the statewide average level, it finds that more than half of Connecticut's public school students attended districts where spending was insufficient to meet the "predicted costs" to achieve the statewide average student test performance level. A direct, negative consequence of spending inadequacy is student underperformance relative to the common student performance target.

This report recommends that the state consider adopting the cost measure as the basis of a new, scientifically grounded, equitable, and adequate formula that allocates more state aid to districts with higher costs. It also suggests that many districts need to increase their spending to meet their predicted costs and close the gap between student performance and the common goal. The exact amount of the additional spending needed partly depends on the state's choices for the student performance target and the common level of district efficiency. For example, this report estimates that in the last year analyzed, with district efficiency held at the statewide average level, an additional $\$ 940$ million, or an increase of 12.3 percent from statewide public K-12 school spending, would have been needed to fully fund the predicted costs required to achieve the statewide average student test performance level in every district.

While the state and local governments now face great fiscal difficulties induced by the COVID-19 pandemic, they should remain committed to the investment in public education, because it will affect Connecticut's economic growth in the long run. 


\section{Introduction}

Connecticut has faced long-running concerns about equity and adequacy in the education finance system. The state has been sued multiple times since the 1970s, including in 2005 by the Connecticut Coalition for Justice in Education Funding (CCJEF). ${ }^{1}$ In 2016, Connecticut Superior Court Judge Thomas Moukawsher ruled against the state in that case (CCJEF v. Rell) and required the state to adopt a method of allocating education grants that is "rationally, substantially, and verifiably connected to creating educational opportunities for students."2 However, in early 2018, the state's highest court reversed Judge Moukawsher's ruling. Although the state adopted a new and arguably improved education aid formula in 2017, between the two court rulings, there remains an ongoing debate among policymakers, practitioners, and advocates on how to further reform the state education aid system (CSFP 2019).

To help advance reform efforts, this report addresses two important and connected questions facing Connecticut policymakers: (1) How much money does each Connecticut school district require to educate its students and to meet a common student test performance target, given that student need differs across districts? (2) Is spending in each

This report considers how much each district must spend for its students to meet a common performance target and if current spending is equitable and adequate relative to that cost. Connecticut school district equitable and adequate relative to the required cost? To answer these questions, this report first reviews the background of Connecticut's education finance system to gain a deeper understanding of the issue. Then, it discusses cost factors that are identified through statistical analysis of recent data. These cost factors are district characteristics that are outside the direct control of local officials at any given point in time but affect school spending. This report examines the cost disparities driven by the differences in these cost factors across school districts. Furthermore, it estimates a measure that it refers to as the "predicted cost," which is defined as the amount of spending required to achieve a common student test performance target given each district's cost factors. Using the predicted cost, this report evaluates the equity and adequacy of Connecticut's school spending and explores the implications of spending inequity and inadequacy for student test performance.

This report reveals large disparities in education costs and cost-adjusted spending across the state. Many districts' spending does not cover the predicted costs required for them to achieve the statewide average student test performance level. Furthermore, districts with lower socioeconomic status, on average, have higher costs, lower cost-adjusted spending, and more severe spending inadequacy.

Based on these findings, this report recommends that the state consider adopting the predicted-cost measure as the basis of a new, equitable, and adequate state aid formula. This report also suggests that more spending is required for many districts, especially the ones with lower socioeconomic status, in order to achieve the statewide average student test performance level or a higher performance target. The exact amount of the additional spending needed partly depends on the student performance target and the assumed common level of district efficiency that are used in calculating the predicted cost.

1 CCJEF members include municipalities, local boards of education, teachers unions, advocacy organizations, parents and grandparents, and public school students.

2 See Page 28 of Memorandum of Decision, Connecticut Coalition for Justice in Education Funding, Inc. v. Rell, Superior Court, Judicial District of Hartford, Docket No. XO7 HHD-CV-14-5037565-S (September 7, 2016). 


\section{Background of Connecticut's Education Finance System}

According to the US Census Bureau's Annual Survey of School System Finances, the contribution from local revenues to Connecticut's public school funding in 2017 was 58 percent-the fourth highest percentage in the country. This heavy reliance on local sources creates disparities in education quality between property-rich school districts, which can afford to spend more, and their property-poor counterparts.

The second-largest revenue source for Connecticut public schools is state aid. Connecticut's education aid system includes more than 10 different aid programs (CSFP 2019). Of these programs, the formula-based Education Cost Sharing (ECS) grants are the largest source of K-12 education aid. The stated goals of ECS grants are to mitigate fiscal disparities among school districts and to enable adherence to the state's constitutional mandate of equal protection under the law and the right to a free and adequate public education.

Connecticut's education finance system has been shaped by several lawsuits over the past five decades. In 1977, the Connecticut Supreme Court ruled in Horton v. Meskill that the state violated Connecticut's constitution by not providing every public school student with an equal educational opportunity. Before this case, the state's school districts each received the same amount of education aid (Wetzler 2004). However, the Connecticut Supreme Court found that this flat-rate aid system was unconstitutional, because it prevented property-poor communities from providing their students with an adequate education. The state legislature responded to this ruling by changing the state aid formulas so that the amount of aid that a school district received would be based on the city or town's property tax capacity and the needs of its students. In 1985, the Connecticut Supreme Court made a follow-up ruling that, despite these changes in the state aid system, the unconstitutional disparities between property-rich and property-poor school districts

Heavy reliance on local revenue sources creates disparities in education quality between property-rich and property-poor districts. persisted. Following this court decision, the state legislature created the ECS grant program, in 1988, to more effectively address the disparities in education finance (Moran et al. 2016). In 2016, the Connecticut Superior Court ruled in CCJEF v. Rell that the state had failed to rationally allocate education grants to create educational opportunities for students. The Connecticut Supreme Court later overturned this decision (CSFP 2018a). Nevertheless, the debate about the equity and the adequacy in Connecticut's education finance system has continued, with ongoing efforts to improve the ECS formula (CSFP 2019).

The structure of ECS is largely the same as it was when the grant program was created more than 30 years ago. The amount of ECS grant funding allocated to a school district is based on three components: the foundation amount, a weighted count of enrolled students, and the base aid ratio. The foundation is the amount of money that the state determines is needed to educate a typical public school student who does not have any additional learning needs. Connecticut set the foundation amount for fiscal year 2019 at $\$ 11,525$ per pupil (CSFP 2018b). The state recognizes 
that a school district with a greater share of at-risk students needs to spend more money than the foundation amount; therefore, in the new formula adopted in 2017, it uses three "need-student" weights (low-income-student weight, concentrated-poverty weight, and English-learner weight) to adjust the number of enrolled students and thus the amount of funding needed. Whereas a typical student without additional learning needs receives a weight of 1.0 in the ECS formula, a low-income student receives a weight of 1.3, and an English-learner a weight of 1.15 (CSFP 2019). For a district with concentrated poverty, which is defined as a district in which more than 75 percent of the students are from low-income households, the state gives an additional weight of 0.05 to each low-income student. After the total school funding is calculated by multiplying the foundation amount by the weighted count of enrolled students, the base aid

In 2017, the contribution from local revenues to Connecticut's public school funding was 58 percent-the fourth highest percentage in the country. ratio determines the share of this amount that ECS grants will fund. ${ }^{3}$ The state uses the base aid ratio to account for differences among municipalities in their capacity for funding local education services and, accordingly, to distribute more grant money to districts with less local fiscal capacity. ${ }^{4}$

ECS has several limitations. First, the program has rarely been fully funded in the past 30 years (Moran et al. 2016; Sullivan 2018). During economic recessions and related fiscal crises, the state often froze or reduced the ECS funding levels, stopped running the ECS formula, and instead distributed ECS grants via block grants. To address this issue, the state legislature passed a law in October 2017 that calls for the phasing in of full funding of ECS over a 10-year period that began with fiscal year 2019. Second, many education advocates do not view the foundation amount as representing the real costs of educating students in Connecticut. It is not derived from data analysis; instead it is based on the historical levels of the foundation amount and has included few increases to account for changes in costs over time (CSFP 2019). Third, obtaining an accurate count of low-income students has become increasingly challenging. The state has relied on eligibility for free or reduced-price lunch (FRPL) to determine low-incomestudent status. However, under the Community Eligibility Provision (CEP) in the federal Healthy, Hunger-Free Kids Act of 2010, FRPL is no longer a reliable measure of low-income students in each

3 School districts are guaranteed to receive at least 1 percent of their total funding through the ECS program (Moran et al. 2016). So-called Alliance Districts-33 state-designated lowest-performing cities and towns-receive a minimum base aid ratio of 10 percent.

4 The formula for calculating the base aid ratio is complex. It takes into account both the total equalized value of taxable property, called the equalized net grand list (ENGL), and the median household income in a school district. In general, districts with lower ENGLs per pupil and lower median household incomes are given higher base aid ratios and therefore receive more ECS grant funding (Moran et al. 2016). In addition, the state gives 19 poor cities and towns an extra 3 to 6 percentage points in the base aid ratio. 
school district. ${ }^{5}$ In addition, Connecticut does not separate special education from the ECS program; instead it incorporates special education funding into the foundation amount in the ECS formula. This treatment creates an incentive for school districts to underfund the costly specialeducation programs and deny services to students with special learning needs. ${ }^{6}$

\section{Measuring Cost Disparities}

Through advanced statistical analysis of recent data, this report finds four cost factors that increase the amount of spending needed for districts to achieve a given student test performance and are outside the direct control of local officials at any given point in time. Based on these cost factors, this report develops a cost index that indicates large disparities in education costs across Connecticut school districts.

This report uses a regression method to analyze the school-district-level data from 2009 through 2013.7 This time span was chosen

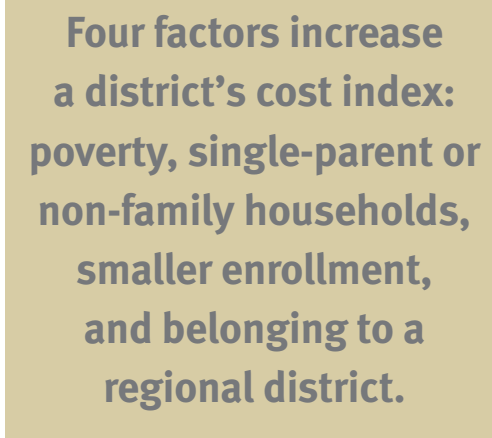
because it is a period for which there are sufficient data on school finances, district characteristics, and student test performance for rigorous statistical analysis. The relationship between school spending and student and district characteristics is believed to be relatively stable, regardless of the time period and how Connecticut tests students. ${ }^{8}$ Therefore, although the state changed the standardized tests in 2015 from the Connecticut Mastery Test (for public elementary and middle school students) and the Connecticut Academic Performance Test (for public high school students) to the Smarter Balanced Test, the general pattern of the results should still be informative and relevant for policymakers. This same type of research can be performed in the future, when more data from the Smarter Balanced Test period become available.

5 The CEP allows all students, not just low-income students, to receive free meals if their districts or schools qualify and participate. To qualify for the CEP, districts and schools must have at least 40 percent of their students directly certified by the state for free meals, without the use of a household application. Using administrative data, the state can directly certify (1) students whose households participate in public benefits programs, such as the Supplemental Nutritional Assistance Program (SNAP), Temporary Assistance for Needy Families (TANF), and Medicaid for children; and (2) students in other programs, such as homeless, runaway, migrant, foster care, and Head Start programs. In districts and schools that qualify for and participate in the CEP, parents of students no longer need to submit an application for FRPL, which was the approach that schools used to collect the student-level meal eligibility data before the CEP took effect. However, states still need the student-level FRPL data to satisfy federal and state school accountability requirements and to run their education aid formulas (if their formulas include FRPL as an input factor), as well as for many other data-reporting purposes. Therefore, the Connecticut State Department of Education requires the CEP districts and schools to continue reporting each student's hypothetical eligibility for FRPL by using the following protocol. These districts and schools should report (1) the FRPL status of directly certified students as eligible for FRPL, (2) the FRPL status of returning students who are not directly certified the same as in the previous year, and (3) the FRPL status of new students who are not directly certified based on the "alternative income survey" that their parents are supposed to complete and return to schools. However, parents of new students have no personal incentive to do so, since their children are already guaranteed to receive free meals in these CEP districts and schools. The resulting student-level hypothetical FRPL data are likely to be inaccurate, drawing serious concerns from state officials. When testifying before the Connecticut General Assembly's Appropriations Committee on March 6, 2019, Connecticut State Department of Education officials highlighted "data integrity" issues in the student-level FRPL data (CSFP 2019).

6 See Jacqueline Rabe Thomas, "State Intervenes in Hartford's Treatment of Students with Disabilities," CT Mirror, August 26, 2011; Jacqueline Rabe Thomas, "State: Bridgeport 'Systematically Violated' Special Education Laws," CT Mirror, January 24, 2014; Brian McCready, "Oxford Parents Question Special Education Services," Oxford Patch, October 11, 2018.

7 See Zhao (2020) for more details of the regression analysis.

8 Duncombe (2006) and Duncombe and Yinger (2011), who conducted cost studies for Kansas and Missouri, respectively, show that the cost estimates are not sensitive to the time periods of the data that are used and are reliable for forecasting purposes. 
The regression approach allows us to answer an important question: Which factors are driving up the costs for school districts to achieve a given student test performance level, when all districts are held to operate at the same efficiency level?' When holding both student test performance and district efficiency at the same levels across districts, this report finds four cost factors that significantly affect school spending; each factor is outside the direct control of local officials at any given point in time.

These cost factors are (1) the percentage of school-age children (aged 5 to 17) from families living in poverty, (2) the percentage of students living in single-parent or non-family households, (3) whether enrollment size is larger or smaller than 2,000 students, and (4) whether a school district is a regional or local district. A district with a higher percentage of school-age children from families living in poverty or a higher percentage of students living in single-parent or non-family households has to spend more to achieve a given student performance level, because those students are likely to receive less time and/or financial resources from their parents. ${ }^{10}$ They are also more likely to learn English as a second language ${ }^{11}$ and have disabilities, ${ }^{12}$ both of which could hamper their ability to study. A small district, specifically one in which fewer than 2,000 students are enrolled, has to spend more to reach a given student test performance level because it is unable to enjoy the cost savings reaped by larger districts, which can spread costs over a greater number of students. ${ }^{13}$ Also, regional school districts experience costs that are higher than those of local school districts to achieve the same student test performance level, perhaps due to the additional expenses associated with coordination among a regional district's member towns.

A cost index based solely on these cost factors allows us to examine the disparities in education costs among Connecticut school districts, when this report effectively holds both student test performance and district efficiency at the same levels across the state. This calculation method avoids rewarding a school district for having a lower efficiency level, since a lower efficiency level would not increase its cost index. It also avoids penalizing a school district for having a higher efficiency level, because a higher efficiency level would not decrease its cost index.

9 Zhao (2020) finds that the identified cost factors are robust, regardless of how student performance is measured. Alternative measures of student performance explored by Zhao (2020) include high school graduation rates, the percentage of high school graduates pursuing higher education, and the growth in student test performance.

10 This report prefers the school-age-child-poverty rate to the percentage of students eligible for free or reduced-price lunch (FRPL) to account for low-income students mainly because since the CEP in the federal Healthy, Hunger-Free Kids Act of 2010 took effect, the percentage of students eligible for FRPL is likely to be inaccurate. (See Footnote 5 for more information about the impact of the CEP on FRPL.) The school-age-child-poverty rate is not affected by the CEP.

11 This report finds that when the percentage of English-learner students and the percentage of school-age children from families living in poverty are concurrently included in the regression, the cost effect of English-learner students is not significant in a statistical sense. This is likely due to districts with a higher percentage of English-learner students tending to also have a higher percentage of school-age children from families living in poverty. Therefore, the cost effect of Englishlearner students is likely, at least partly, absorbed by the cost effect of school-age-child poverty.

12 This report does not directly include the percentage of special-education students as a cost factor because it may be affected by schools' or districts' choices. Districts have discretion in accommodating students' request for special education. Since special education is more costly than standard education and the state does not directly account for the number of special-education students in the allocation of state education aid, some districts may have a financial incentive to reduce the number of students receiving special education. Because districts with a higher percentage of school-age children from families living in poverty tend to have a higher percentage of special-education students, the cost effect of special-education students is likely, at least partially, reflected by the cost effect of school-age-child poverty.

13 In theory, the state could mandate small districts to consolidate. However, in the absence of such state-level policy, the size of district enrollment is still outside the direct control of local officials at any given point in time. In addition, the regression results suggest that on average, school district consolidation may not produce net cost savings, because forming or joining a regional district triggers additional costs possibly related to coordination with other towns in the same regional district. Table 1 in the online appendix shows similarly sized coefficients on the indicator variable for an enrollment of fewer than 2,000 students and the indicator variable for a district being a regional school district. 


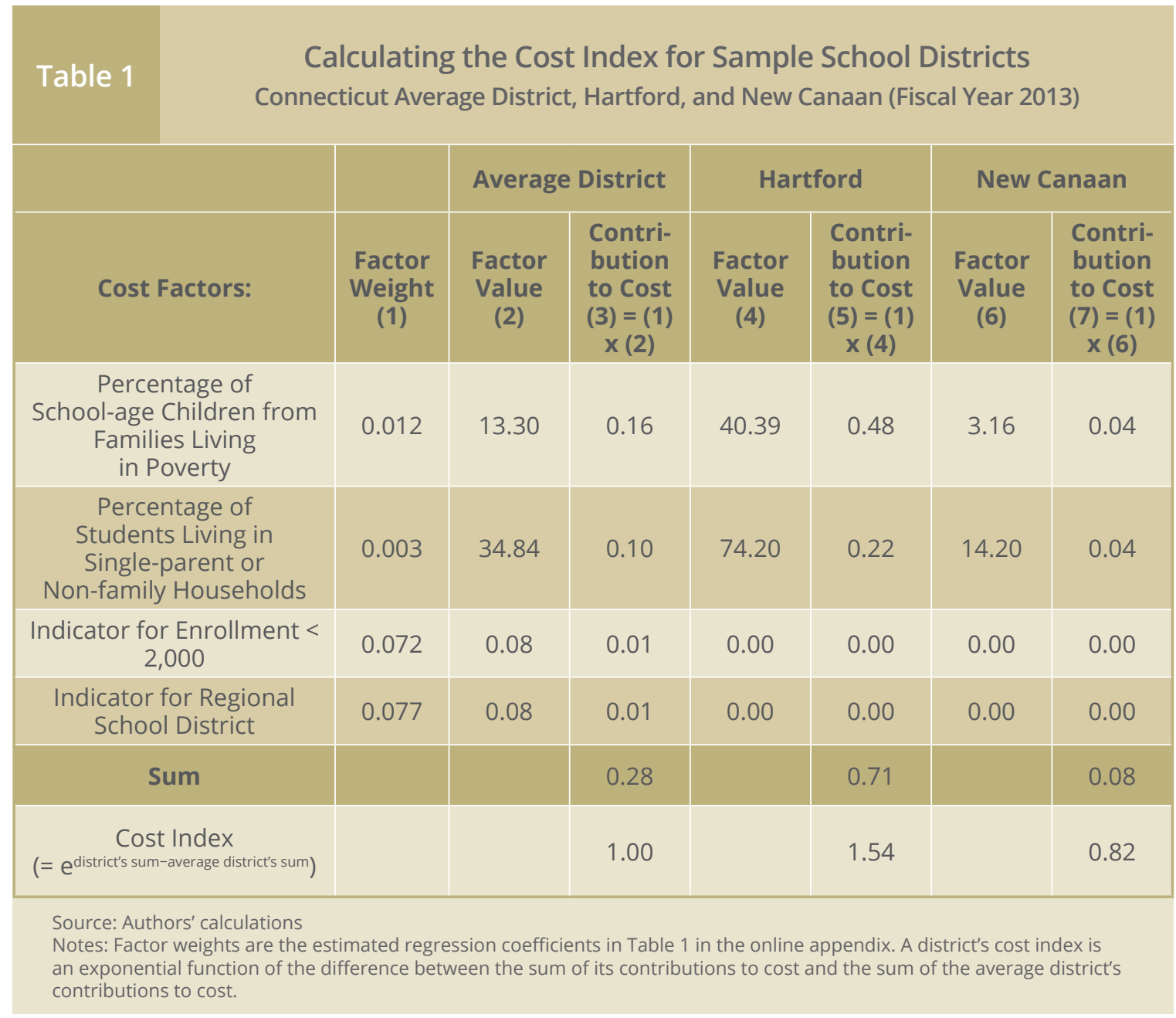

Table 1 illustrates how the cost index is calculated for two sample districts-the Hartford school district (an example of a large, poor, urban school district) and the New Canaan school district (an example of a wealthy, suburban school district)-and an average district in fiscal year 2013. This report constructs this average district by assigning it the statewide enrollment-weighted average values of the cost factors that year. The cost index shows how high or low a district's costs are relative to the average district's costs. ${ }^{14}$ By construction, the cost index for the average district is equal to 1 , since it compares with itself.

The Hartford school district had a cost index of 1.54 in fiscal year 2013, meaning that the district's costs per pupil were 54 percent higher than those of the average district. This is because Hartford had a significantly higher percentage of school-age children from families living in poverty and a significantly higher percentage of students living in single-parent or non-family households. In comparison, New Canaan, with a cost index of 0.82 in fiscal year 2013, had costs per pupil that were about 18 percent lower than those of the average district. These lower costs were driven mostly by New Canaan's lower percentage of school-age children from families living in poverty and lower percentage of students living in single-parent or non-family households, compared with the average district. ${ }^{15}$

14 This report uses the estimated coefficient on each cost factor from the regression analysis as a "weight" to indicate how much this cost factor contributes to education costs. See Table 1 in the online appendix for the full regression results.

15 See Tables 2 and 3 in the online appendix for the values of the cost factors and the cost index for each Connecticut school district in fiscal year 2013. The ratio of the maximum cost index to the minimum cost index for Connecticut in that year is 1.90. It lies within the range of the maximum-to-minimum ratios for other states estimated in previous studies. Imazeki and Reschovsky (2006) estimate that the maximum-to-minimum ratio for Texas in fiscal year 2002 was 8.05, and Duncombe and Yinger (2005) estimate that the maximum-to-minimum ratio for New York in fiscal year 2001 was 1.81. 


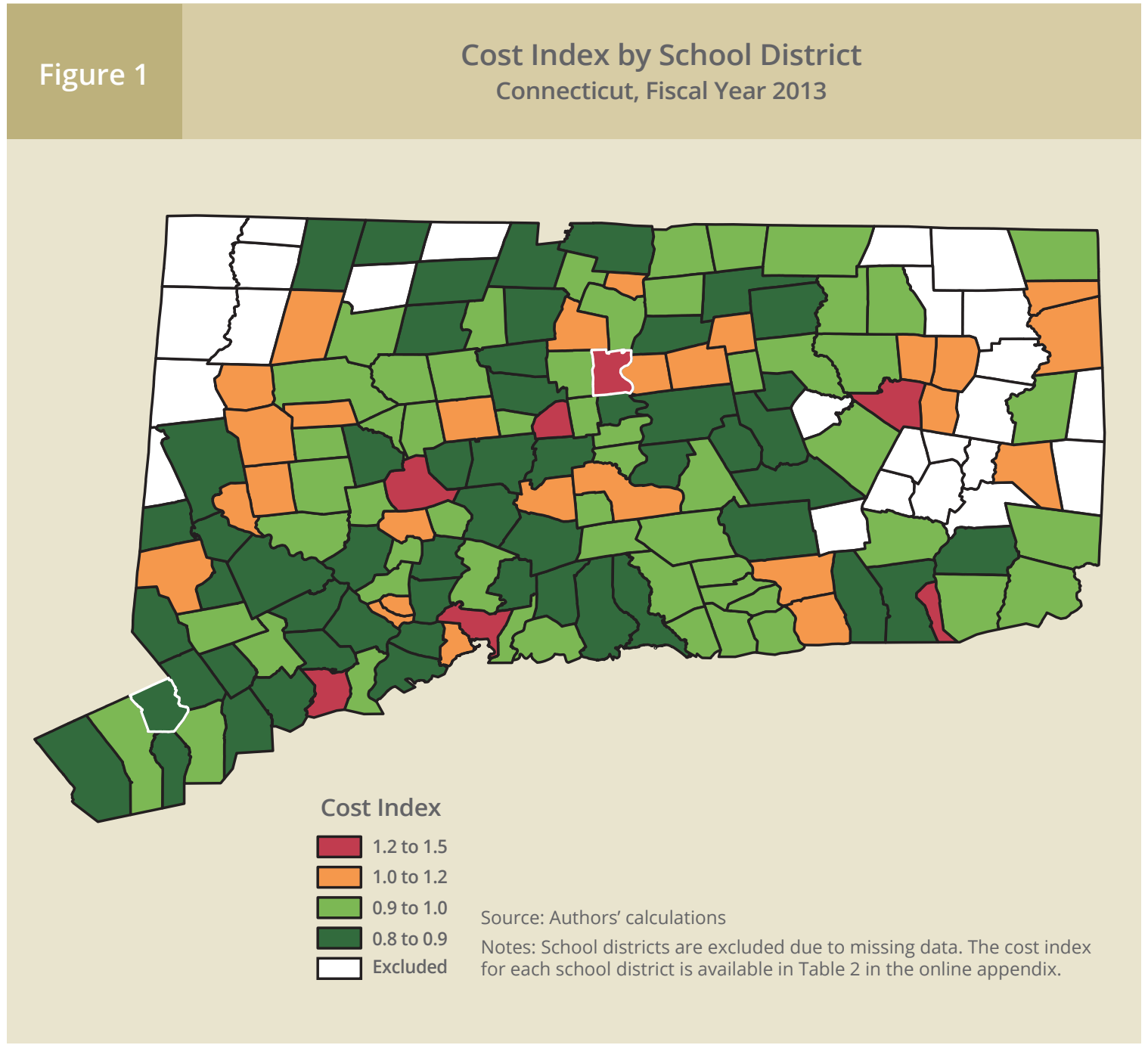

The cost index value is not evenly distributed across the state (Figure 1). The highest cost indexes are concentrated among the largest school districts that are also poor and urban. The wealthy suburbs tend to have the lowest cost indexes. In particular, Fairfield County, which is in the southwest corner of the state and near New York City, has a large cluster of the lowest-cost school districts.

On average, the cost index is higher for school districts that the state identifies as having lower socioeconomic status and a higher level of student need. The Connecticut State Department of Education uses a classification system called District Reference Groups (DRGs), which sorts districts according to socioeconomic characteristics (Connecticut State Department of Education 2006). It uses the following seven variables as indicators of students' socioeconomic status and level of need: (1) the median family income for households with children in public schools; (2) the percentage of parents with a bachelor's degree or higher; (3) the percentage of public school students with parents holding jobs in executive, managerial, or professional specialty occupations; (4) the percentage of public school students living in families without a spouse present or in non-family households; (5) the percentage of public school students eligible to receive free or reduced-price 


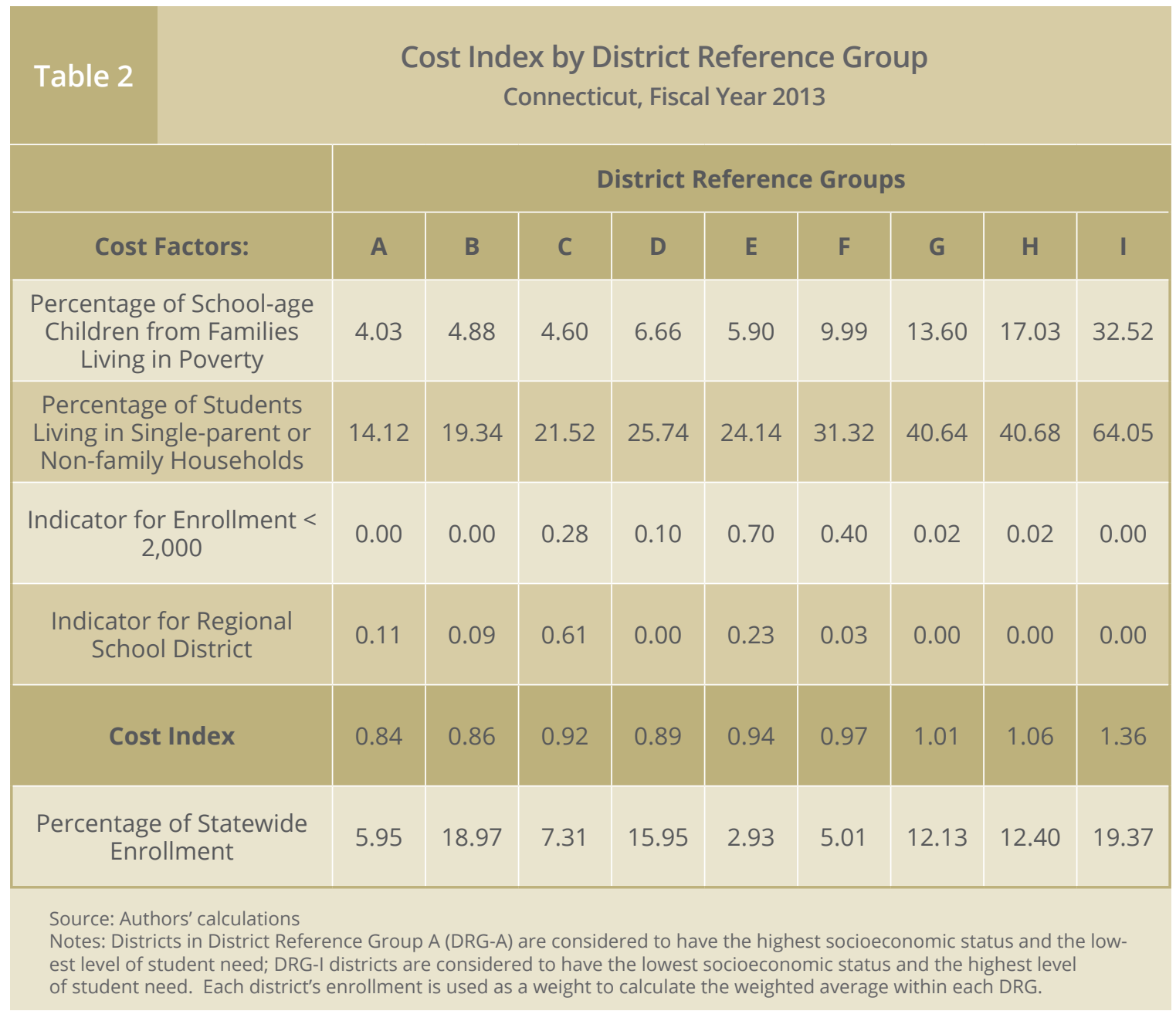

meals; (6) the percentage of public school students whose family members speak a language other than English at home; and (7) district enrollment. Then, the State Department of Education uses a statistical approach to categorize districts in nine groups, labeled in alphabetic order from A through I. Districts in DRG-A are considered to have the highest socioeconomic status and the lowest level of student need; DRG-I districts are considered to have the lowest socioeconomic status and the highest level of student need. The state created the DRG system to help school districts make more appropriate comparisons.

Table 2 shows that districts in DRG-I, which collectively enroll nearly one-fifth of the state's public school students, have the highest average cost index. This is because these districts have, on average, the highest rate of school-age-child poverty and the highest percentage of students living in single-parent or non-family households. On the other end of the spectrum, districts in DRG-A have the lowest average cost index, because they have, on average, the lowest rate of school-age-child poverty and the lowest percentage of students living in single-parent or non-family households.

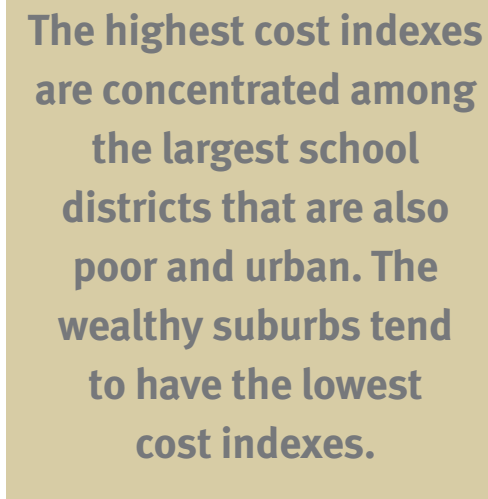
are concentrated among the largest schoo districts that are also poor and urban. The to have the lowest cost indexes. 


\begin{tabular}{|c|c|c|c|}
\hline \multirow[t]{2}{*}{ Table 3} & \multirow[b]{2}{*}{ Average District } & \multirow[b]{2}{*}{ Hartford } & \multirow[t]{2}{*}{$\begin{array}{l}\text { chool Districts } \\
\text { Year 2013) }\end{array}$} \\
\hline & & & \\
\hline $\begin{array}{l}\text { Current Spending per } \\
\text { Pupil in } \$ 1,000 \text { (1) }\end{array}$ & 15.12 & 16.53 & 18.93 \\
\hline Cost Index (2) & 1.00 & 1.54 & 0.82 \\
\hline $\begin{array}{l}\text { Cost-adjusted Current } \\
\text { Spending per Pupil in } \\
\$ 1,000(3)=(1) /(2)\end{array}$ & 15.12 & 10.74 & 23.01 \\
\hline
\end{tabular}

\section{Evaluating Equity and Adequacy in School Spending}

This report assesses equity and adequacy in districts' spending based on education costs and the student performance target. The assessment suggests that, after cost adjustments, there are large disparities in spending across school districts. Many districts' spending is inadequate to achieve the statewide average student performance level, given their high costs. Ensuring that every district is financially equipped to reach that performance target would require a significant increase in school spending.

It is important that policymakers consider cost differentials across school districts when evaluating equity and adequacy in school spending. The cost index shows that districts with different levels of the cost factors have to spend different amounts of money

Districts with different levels of the cost factors have to spend different amounts of money to achieve the same level of student performance. to achieve the same target level of student test performance. For this reason, current spending adjusted by the cost index portrays inequity more accurately than does unadjusted current spending.

Table 3 illustrates how cost-adjusted current spending is calculated for two sample districts (Hartford and New Canaan) and the average district. Before cost adjustments, Hartford's current spending per pupil in fiscal year 2013 was 13 percent lower than New Canaan's. But because Hartford's cost index was much higher than New Canaan's, its cost-adjusted current spending per pupil was 53 percent lower than that of the wealthier district. ${ }^{16}$

16 See Tables 2 and 3 in the online appendix for the value of cost-adjusted current spending per pupil for other school districts in fiscal year 2013. 


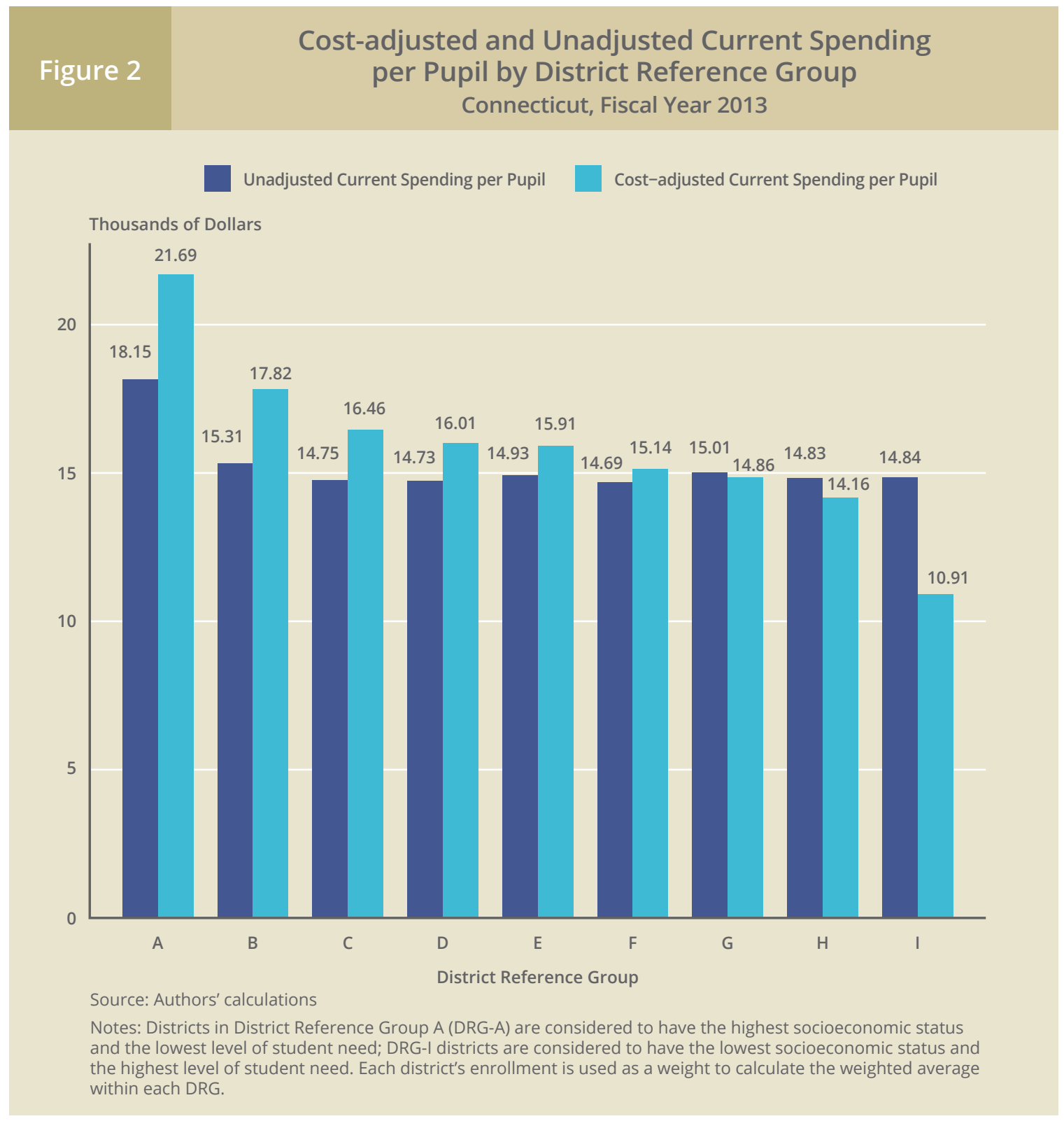

Cost-adjusted current spending per pupil has a wider range than unadjusted current spending per pupil among school districts and is generally lower in districts with lower socioeconomic status (Figure 2). Except for DRG-A, all of the DRGs had similar unadjusted current spending per pupil in fiscal year 2013. However, due to differences in their cost indexes, there was significant inequity in cost-adjusted current spending per pupil among the DRGs. On the one hand, DRG-I had the lowest average cost-adjusted current spending per pupil, but not because it had the lowest unadjusted current spending per pupil; it was because the DRG had the highest cost index. On the other hand, DRG-A had the highest cost-adjusted current spending per pupil, because it had both the highest unadjusted current spending per pupil and the lowest cost index.

To evaluate the adequacy of school spending, policymakers first need to know how much money each district must spend at a state-selected common efficiency level to achieve a stateselected common target for student test performance given the district's cost factors. In this report, every district's efficiency is held at the same level, so that less efficient districts are not rewarded or more efficient districts are not penalized. This report calls the required spending derived from this calculation the "predicted cost." 


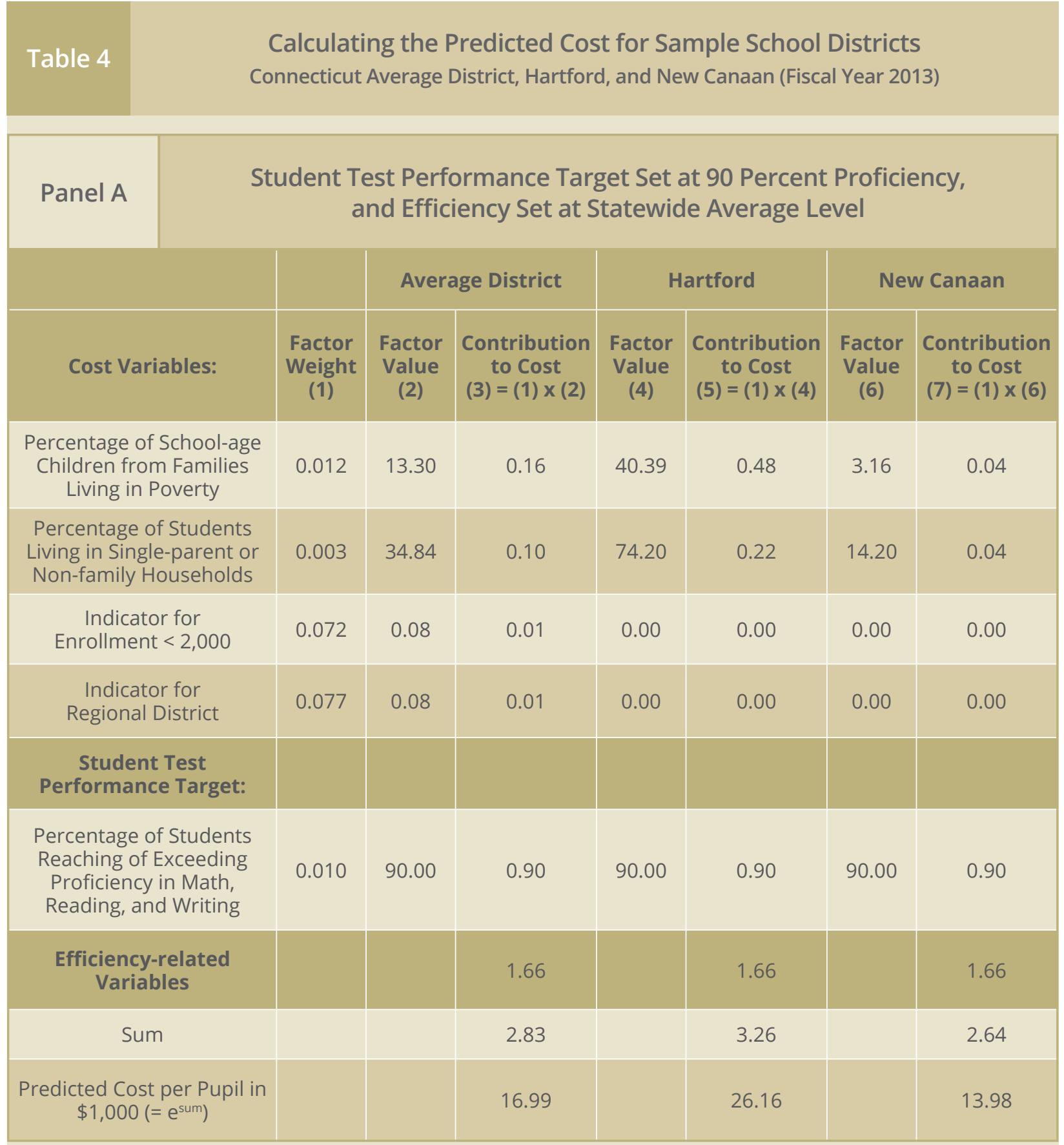

Source: Authors' calculations

Notes: Factor weights are the estimated regression coefficients in Table 1 in the online appendix. A district's predicted cost per pupil is an exponential function of the sum of its contributions to cost.

Table 4 illustrates how to calculate the predicted cost for the sample districts, with different policy choices for the student performance target and the common district efficiency level. In Panel A, it is assumed that the performance target for all districts is to have 90 percent of students reach or exceed the proficiency level and every district's efficiency is held at the same statewide average level. ${ }^{17}$ This allows school districts to vary only in the values of the cost factors when their predicted costs are calculated. The calculations show that the predicted cost per pupil is nearly 1.9 times as high for Hartford as it is for New Canaan.

17 Under this assumption, the same enrollment-weighted statewide average values of the efficiency-related variables are assigned to each district. This report uses the estimated coefficients from the regression analysis as "weights" to indicate how much each factor contributes to the predicted cost. 


\begin{tabular}{|c|c|c|c|c|c|c|c|}
\hline \multicolumn{8}{|c|}{$\begin{array}{l}\text { Calculating the Predicted Cost for Sample School Districts } \\
\text { Connecticut Average District, Hartford, and New Canaan (Fiscal Year 2013) }\end{array}$} \\
\hline \multicolumn{8}{|c|}{$\begin{array}{c}\text { Student Test Performance Target Set at Statewide Average Level, } \\
\text { and Efficiency Set at Statewide Average Level }\end{array}$} \\
\hline & & \multicolumn{2}{|c|}{ Average District } & \multicolumn{2}{|c|}{ Hartford } & \multicolumn{2}{|c|}{ New Canaan } \\
\hline Cost Variables: & $\begin{array}{l}\text { Factor } \\
\text { Weight } \\
\text { (1) }\end{array}$ & $\begin{array}{l}\text { Factor } \\
\text { Value } \\
\text { (2) }\end{array}$ & $\begin{array}{l}\text { Contribution } \\
\text { to Cost } \\
(3)=(1) \times(2)\end{array}$ & $\begin{array}{l}\text { Factor } \\
\text { Value } \\
\text { (4) }\end{array}$ & $\begin{array}{l}\text { Contribution } \\
\text { to Cost } \\
(5)=(1) \times(4)\end{array}$ & $\begin{array}{l}\text { Factor } \\
\text { Value } \\
\text { (6) }\end{array}$ & $\begin{array}{l}\text { Contribution } \\
\text { to Cost } \\
(7)=(1) \times(6)\end{array}$ \\
\hline $\begin{array}{c}\text { Percentage of School-age } \\
\text { Children from Families } \\
\text { Living in Poverty }\end{array}$ & 0.012 & 13.30 & 0.16 & 40.39 & 0.48 & 3.16 & 0.04 \\
\hline $\begin{array}{l}\text { Percentage of Students } \\
\text { Living in Single-parent or } \\
\text { Non-family Households }\end{array}$ & 0.003 & 34.84 & 0.10 & 74.20 & 0.22 & 14.20 & 0.04 \\
\hline $\begin{array}{l}\text { Indicator for } \\
\text { Enrollment }<2,000\end{array}$ & 0.072 & 0.08 & 0.01 & 0.00 & 0.00 & 0.00 & 0.00 \\
\hline $\begin{array}{l}\text { Indicator for } \\
\text { Regional District }\end{array}$ & 0.077 & 0.08 & 0.01 & 0.00 & 0.00 & 0.00 & 0.00 \\
\hline \multicolumn{8}{|l|}{$\begin{array}{c}\text { Student Test } \\
\text { Performance Target: }\end{array}$} \\
\hline $\begin{array}{l}\text { Percentage of Students } \\
\text { Reaching of Exceeding } \\
\text { Proficiency in Math, } \\
\text { Reading, and Writing }\end{array}$ & 0.010 & 82.68 & 0.83 & 82.68 & 0.83 & 82.68 & 0.83 \\
\hline $\begin{array}{c}\text { Efficiency-related } \\
\text { Variables }\end{array}$ & & & 1.66 & & 1.66 & & 1.66 \\
\hline Sum & & & 2.76 & & 3.19 & & 2.56 \\
\hline $\begin{array}{l}\text { Predicted Cost per Pupil in } \\
\qquad \$ 1,000\left(=\mathrm{e}^{\text {sum }}\right)\end{array}$ & & & 15.79 & & 24.31 & & 12.99 \\
\hline
\end{tabular}

Source: Authors' calculations

Notes: Factor weights are the estimated regression coefficients in Table 1 in the online appendix. A district's predicted cost per pupil is an exponential function of the sum of its contributions to cost.

In Panel B, the student performance target is lowered to the statewide average student test performance level, which is 82.7 percent of students reaching or exceeding the proficiency level. Each district's efficiency is still held at the statewide average efficiency level, as in Panel A. Under the lower student performance target, the predicted cost per pupil accordingly declines for all districts. Nonetheless, the ratio of Hartford's predicted cost to New Canaan's predicted cost remains unchanged, because this ratio depends on only the cost factors. 


\begin{tabular}{|c|c|c|c|c|c|c|c|}
\hline \multirow{3}{*}{$\begin{array}{l}\text { Panel C } \\
\text { Cost Variables: }\end{array}$} & \multicolumn{7}{|c|}{$\begin{array}{l}\text { udent Test Performance Target Set at Statewide Average Level, } \\
\text { and Efficiency Set at Statewide Top } 25 \text { Percent Level }\end{array}$} \\
\hline & \multirow[b]{2}{*}{$\begin{array}{l}\text { Factor } \\
\text { Weight } \\
\text { (1) }\end{array}$} & \multicolumn{2}{|c|}{ Average District } & \multicolumn{2}{|c|}{ Hartford } & \multicolumn{2}{|c|}{ New Canaan } \\
\hline & & $\begin{array}{l}\text { Factor } \\
\text { Value } \\
\text { (2) }\end{array}$ & $\begin{array}{l}\text { Contribution } \\
\text { to Cost } \\
(3)=(1) \times(2)\end{array}$ & $\begin{array}{l}\text { Factor } \\
\text { Value } \\
\quad(4)\end{array}$ & $\begin{array}{l}\text { Contribution } \\
\text { to Cost } \\
(5)=(1) \times(4)\end{array}$ & $\begin{array}{l}\text { Factor } \\
\text { Value } \\
\text { (6) }\end{array}$ & $\begin{array}{l}\text { Contribution } \\
\text { to Cost } \\
(7)=(1) \times(6)\end{array}$ \\
\hline $\begin{array}{l}\text { Percentage of School-age } \\
\text { Children from Families } \\
\text { Living in Poverty }\end{array}$ & 0.012 & 13.30 & 0.16 & 40.39 & 0.48 & 3.16 & 0.04 \\
\hline $\begin{array}{l}\text { Percentage of Students } \\
\text { Living in Single-parent or } \\
\text { Non-family Households }\end{array}$ & 0.003 & 34.84 & 0.10 & 74.20 & 0.22 & 14.20 & 0.04 \\
\hline $\begin{array}{l}\text { Indicator for } \\
\text { Enrollment }<2,000\end{array}$ & 0.072 & 0.08 & 0.01 & 0.00 & 0.00 & 0.00 & 0.00 \\
\hline $\begin{array}{l}\text { Indicator for } \\
\text { Regional District }\end{array}$ & 0.077 & 0.08 & 0.01 & 0.00 & 0.00 & 0.00 & 0.00 \\
\hline \multicolumn{8}{|l|}{$\begin{array}{c}\text { Student Test } \\
\text { Performance Target: }\end{array}$} \\
\hline $\begin{array}{l}\text { Percentage of Students } \\
\text { Reaching of Exceeding } \\
\text { Proficiency in Math, } \\
\text { Reading, and Writing }\end{array}$ & 0.010 & 82.68 & 0.83 & 82.68 & 0.83 & 82.68 & 0.83 \\
\hline $\begin{array}{l}\text { Efficiency-related } \\
\text { Variables }\end{array}$ & & & 1.59 & & 1.59 & & 1.59 \\
\hline Sum & & & 2.69 & & 3.12 & & 2.50 \\
\hline $\begin{array}{l}\text { Predicted Cost per Pupil in } \\
\qquad \$ 1,000\left(=\mathrm{e}^{\text {sum }}\right)\end{array}$ & & & 14.77 & & 22.74 & & 12.15 \\
\hline
\end{tabular}

Source: Authors' calculations

Notes: Factor weights are the estimated regression coefficients in Table 1 in the online Appendix. A district's predicted cost per pupil is an exponential function of the sum of its contributions to cost.

In Panel C, the student performance target continues to be the statewide average student test performance level, but the common district efficiency level is raised to the statewide top 25 percent district efficiency level. ${ }^{18}$ As a result, the predicted cost per pupil drops further across the state.

The state faces tradeoffs in using a student performance target and a common district efficiency level as policy levers to influence the predicted cost. As Table 4 shows, the state can reduce each district's predicted cost and therefore ultimately decrease the state's funding responsibility

18 This report first calculates the actual contribution of the efficiency-related variables to the predicted cost per pupil for each district and then ranks them from low to high. Next, it takes the 25 th percentile value from this distribution as the top 25 percent district efficiency level in the state. 


\begin{tabular}{|c|c|c|c|}
\hline \multirow[t]{2}{*}{ Table 5} & \multirow[t]{2}{*}{$\begin{array}{l}\text { Proficienc } \\
\text { ticut Average Distr }\end{array}$} & \multirow[t]{2}{*}{$\begin{array}{l}\text { Ratio ar } \\
\text { tudents } \\
\text { ple Scho } \\
\text {, and Nen }\end{array}$} & \multirow[t]{2}{*}{$\begin{array}{l}\text { al Spending } \\
\text { Exceed } \\
\text { al Year 2013) }\end{array}$} \\
\hline & & & \\
\hline $\begin{array}{l}\text { Current Spending per } \\
\text { Pupil in } \$ 1,000 \text { (1) }\end{array}$ & 15.12 & 16.53 & 18.93 \\
\hline $\begin{array}{l}\text { Predicted Cost per } \\
\text { Pupil in } \$ 1,000 \text { (2) }\end{array}$ & 16.99 & 26.16 & 13.98 \\
\hline $\begin{array}{l}\text { Spending-to-cost Ratio } \\
(3)=(1) /(2)\end{array}$ & 0.89 & 0.63 & 1.35 \\
\hline $\begin{array}{c}\text { Additional Spending } \\
\text { Needed per Pupil in } \\
\$ 1,000 \\
(4)=(2)-(1)\end{array}$ & 1.87 & 9.62 & 0.00 \\
\hline $\begin{array}{l}\text { Additional Spending } \\
\text { Needed as Percentage } \\
\text { of Current Spending }(\%) \\
(5)=[(4) /(1)] \times 100\end{array}$ & 12.37 & 58.20 & 0.00 \\
\hline
\end{tabular}

by lowering the student performance target and/or raising the assumed common level of district efficiency. However, a lower student performance target would mean lower-quality education for many districts. Also, a higher-than-average efficiency level may not be feasible for many districts in the short term, especially if it requires large upfront investments in hiring more and higher-quality teachers and upgrading teaching equipment. For illustration purposes, the rest of this report makes the same assumptions as those in Panel B, that the common student performance target is equal to the statewide average percentage of students reaching or exceeding the proficiency level and the common district efficiency level is equal to the statewide average district efficiency level. In addition, it should be noted that spending the same amount of money as the predicted cost does not guarantee that a school district will achieve the student test performance target on which the predicted cost is based. If the district operates at an efficiency level that is lower than the level that was assumed in calculating the predicted cost, the district will not effectively help students learn and will not achieve the performance target. The question of how the state can increase school efficiency is beyond the scope of this report, but it is an important issue that deserves a separate study.

Having the predicted cost to achieve a performance target provides policymakers with a scientific basis to evaluate the adequacy of each school district's spending. Using the sample districts in fiscal year 2013, Table 5 shows that a ratio of current spending to the predicted cost can be 


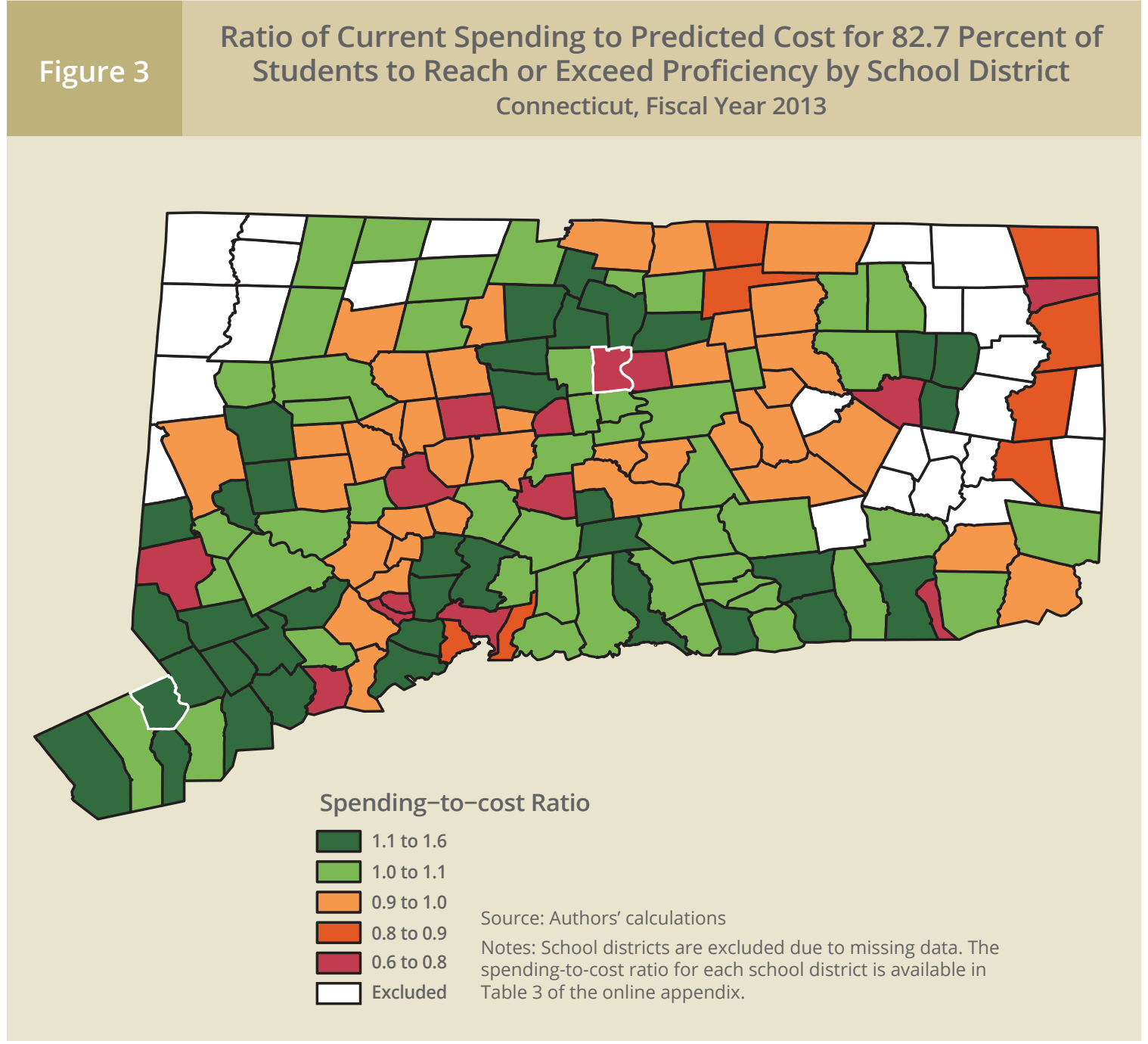

calculated as a measure of spending adequacy for achieving a common performance target, which in this case is assumed to be the statewide average percentage of students reaching or exceeding the proficiency level: 82.7 percent. In fiscal year 2013, Hartford's current spending was 32 percent lower than its predicted cost, which suggests that its spending was inadequate for achieving this target. Raising Hartford's current spending to the adequate

\section{Current spending} adjusted by the cost index portrays inequity more accurately than does unadjusted current spending. level (which is the same amount as its predicted cost) would have required an additional spending of $\$ 7,780$ per pupil, or a 47 percent increase in current spending. In contrast, New Canaan's current spending was 46 percent higher than its predicted cost in fiscal year 2013. This suggests that the district's spending was adequate for achieving the performance target and therefore New Canaan would not have needed additional spending. ${ }^{19}$

There is large variation in spending adequacy across the state (Figure 3). Spending exceeded predicted costs in most of Fairfield

19 See Tables 2 and 3 in the online appendix for the values of the spending-to-cost ratio and additional spending needed per pupil for other school districts to achieve the target of 82.7 percent of students reaching or exceeding the proficiency level in fiscal year 2013. 


\begin{tabular}{|c|c|c|c|c|c|c|c|c|c|}
\hline \multicolumn{10}{|c|}{$\begin{array}{c}\text { Spending-to-cost Ratio and Additional Spending Needed for } 82.7 \text { Percent } \\
\text { of Students to Reach or Exceed Proficiency by District Reference Group } \\
\text { Connecticut, Fiscal Year } 2013\end{array}$} \\
\hline & \multicolumn{9}{|c|}{ District Reference Groups } \\
\hline & A & B & C & D & E & $\mathbf{F}$ & G & $\mathbf{H}$ & I \\
\hline $\begin{array}{l}\text { Current Spending } \\
\text { per Pupil in } \$ 1,000\end{array}$ & 18.15 & 15.31 & 14.73 & 14.75 & 14.93 & 14.69 & 15.01 & 14.83 & 14.84 \\
\hline $\begin{array}{l}\text { Predicted Cost per Pupil } \\
\text { in } \$ 1,000\end{array}$ & 13.24 & 13.57 & 14.47 & 14.13 & 14.82 & 15.33 & 15.98 & 16.68 & 21.51 \\
\hline Spending-to-cost Ratio & 1.37 & 1.13 & 1.01 & 1.04 & 1.01 & 0.96 & 0.94 & 0.90 & 0.69 \\
\hline $\begin{array}{l}\text { Additional Spending } \\
\text { Needed per Pupil } \\
\text { in } \$ 1,000\end{array}$ & 0.00 & 0.00 & 0.43 & 0.25 & 0.33 & 0.90 & 1.36 & 2.26 & 6.67 \\
\hline $\begin{array}{l}\text { Additional Spending } \\
\text { Needed as Percentage of } \\
\text { Current Spending (\%) }\end{array}$ & 0.00 & 0.00 & 3.35 & 1.89 & 2.38 & 6.51 & 10.01 & 16.95 & 45.28 \\
\hline $\begin{array}{l}\text { Source: Authors' calculations } \\
\text { Notes: Districts in Distric Refere } \\
\text { est level of student need; DRG- } \\
\text { student need. Each district's en }\end{array}$ & son & ser & . & $\begin{array}{l}\text { to hav } \\
\text { lowest } \\
\text { late the }\end{array}$ & $\begin{array}{l}\text { the hig } \\
\text { ocioec } \\
\text { weighte }\end{array}$ & $\begin{array}{l}\text { socic } \\
\text { hic sta }\end{array}$ & mic s & $\begin{array}{l}\mathrm{s} \text { and th } \\
\text { hest leve }\end{array}$ & $\begin{array}{l}\text { low- } \\
\text { of }\end{array}$ \\
\hline
\end{tabular}

County, coastal districts, and some inland suburban districts in fiscal year 2013; however, in 45 percent of Connecticut school districts, spending was inadequate for achieving the target of 82.7 percent of students reaching or exceeding the proficiency level. Statewide, 51.5 percent of public school students were enrolled in districts where spending was inadequate for achieving this target.

Spending inadequacy is more severe in districts with lower socioeconomic status and a higher level of student need (Table 6). On the one hand, in fiscal year 2013, districts in DRG-I-all of which are large, high-need, low-socioeconomic-status, urban districts-on average, spent 31 percent less than what was required to achieve a target of 82.7 percent of students reaching or exceeding the proficiency level.
To evaluate adequacy, policymakers need to know a district's "predicted cost"-how much it must spend to achieve a performance target given its cost factors. 


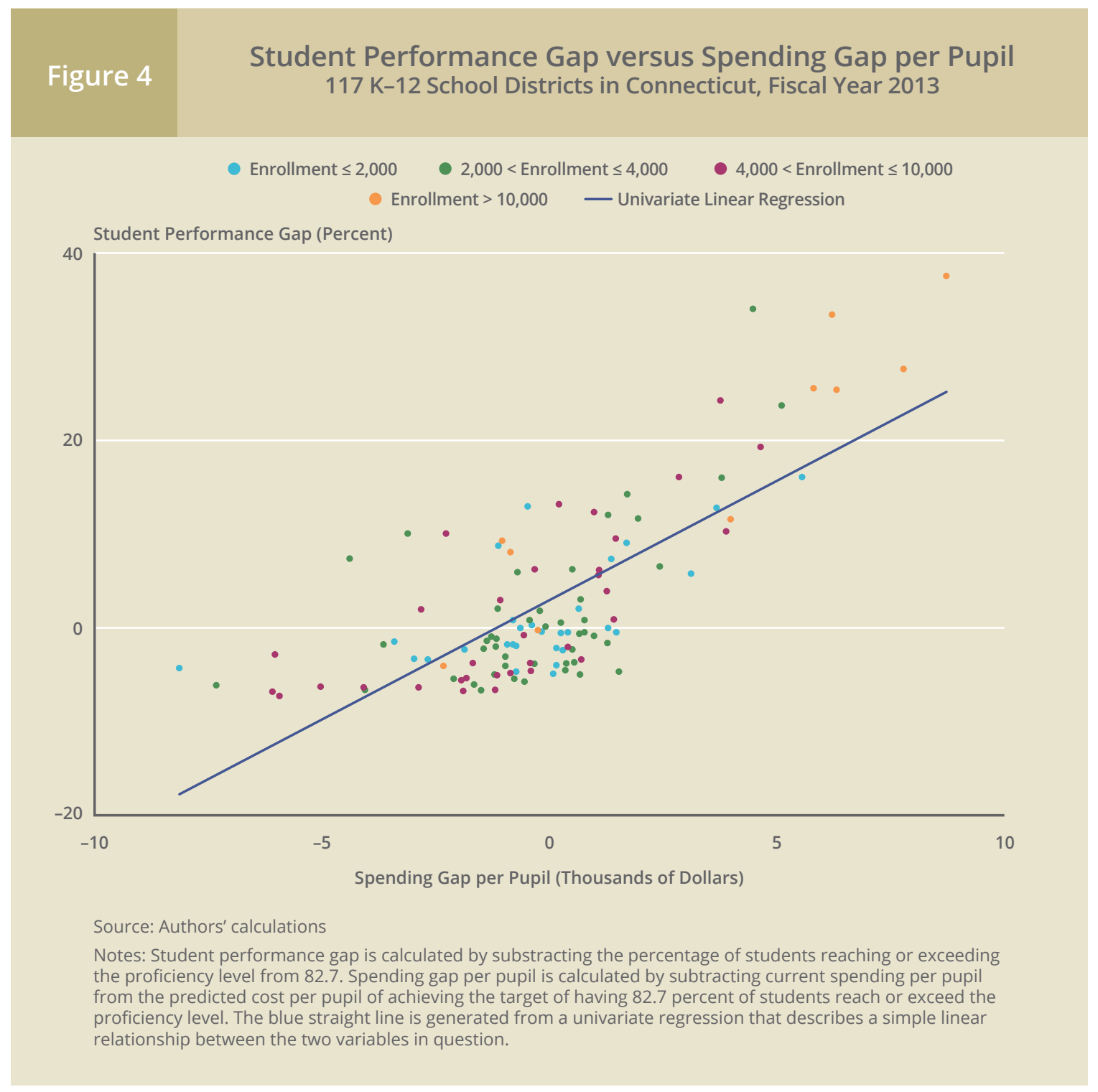

\section{Statewide, 51.5 percent} of public school students were enrolled in districts where spending was inadequate for achieving the average student performance level.
Their spending needed to increase more than 45 percent to be adequate for achieving this target, by this report's definition. On the other hand, the affluent, low-need, suburban districts of DRG-A, on average, spent 37 percent more than their predicted costs for achieving the target of 82.7 percent of students reaching or exceeding the proficiency level. Because they already spent more than enough to achieve this target, they did not need additional spending.

Inadequate school spending has a negative impact on student test performance. Figure 4 shows that the larger the gap is between current spending and the predicted cost, the larger it is between student test performance and the given performance target. Many school districts need more spending to close the performance gap. 


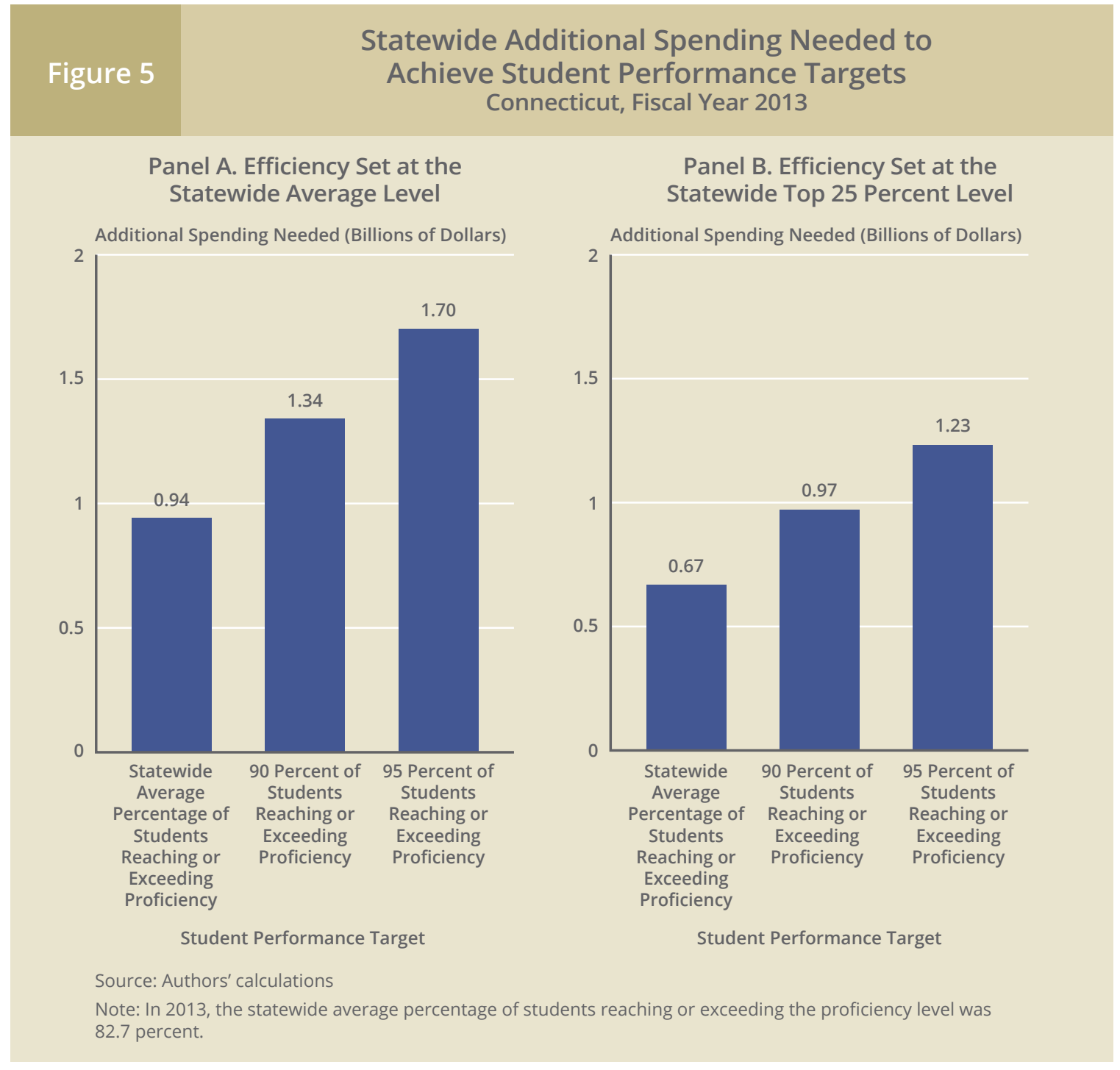

The additional spending needed increases with the performance target when the common district efficiency level is held constant (Figure 5). In Panel A, where the common district efficiency level is assumed to be the statewide average, the state as a whole would have needed about $\$ 940$ million in additional spending, which is a 12.3 percent increase from the $\$ 7.63$ billion statewide current spending for 2013, for every district to have achieved the statewide average student test performance level. If the performance target were hiked to 90 or 95 percent of students reaching or exceeding the proficiency level, statewide school spending would have needed to increase $\$ 1.34$ billion (17.6 percent) or $\$ 1.70$ billion (22.3 percent), respectively.

Furthermore, the additional spending needed decreases with the assumed common level of district efficiency when the student performance target is held constant. In Panel B, where the common district efficiency level is assumed to be the statewide top 25 percent level, the state as a whole would have needed about $\$ 670$ million in additional spending for every district to have achieved the statewide average student test performance level. That amount is about 28 percent less than the additional spending needed statewide to achieve the same student performance target in Panel A, which assumes a lower common level of district efficiency. 


\section{Conclusion}

This report shows great inequity in education costs and cost-adjusted spending across Connecticut school districts. Holding student test performance and efficiency constant across districts, it finds that four district characteristics, each of which is outside the direct control of local officials at any given point in time, affect education costs: (1) the percentage of school-age children from families living in poverty, (2) the percentage of public school students living in single-parent or non-family households, (3) whether a district enrolls fewer or more than 2,000 students, and (4) whether it is a regional school district or a local school district. On average, districts with lower socioeconomic status have a higher cost index and lower cost-adjusted spending.

This report also reveals inadequacy in many school districts' spending, which has a negative impact on student test performance. In fiscal year 2013, more than half of Connecticut's public school students were enrolled in districts where spending was insufficient to cover the predicted cost of achieving the statewide average student test performance level, which was 82.7 percent of students reaching or exceeding the proficiency level on the state's standardized tests in that year. Spending inadequacy is more severe in districts with lower socioeconomic status. More important, spending inadequacy is linked to student underperformance relative to the common target.

To better address school spending inequity and inadequacy, the state should consider implementing the measure of the predicted cost for achieving a common student performance target given each district's cost factors. The predicted cost could be used as the basis of a new formula that allocates more state education aid to districts with higher costs. Because the cost factors, their "weights," and the predicted cost are derived from data research, they are more rational and scientifically defensible than the foundation amount and the "need-student" weights used in Connecticut's current ECS formula. The state uses the foundation amount to represent the cost of educating a typical public school student who does not have any additional learning needs. However, each year's foundation amount is "based on past foundation amounts and not derived using verifiable education spending data" (CSFP 2019, p. 49). Also, the foundation amount is not based directly on any student performance target. And although the current formula contains three "need-student" weights (low-income student, concentrated poverty, and English-learner) to adjust the foundation amount for each district, these weights are not derived from data analysis.

This report also suggests that many districts need to increase their spending in order to close the gap between their student performance level and the common target. In general, districts with lower socioeconomic status need the larger increases in school spending. For example, districts in DRG-I would have needed to increase their 2013 spending by more than 45 percent to achieve the common target of 82.7 percent of students reaching or exceeding the proficiency level.

Meeting these needs for additional spending would require significantly more funding from the state and municipalities. Given that the districts in greater need of more spending are often poor and lack property wealth to tap for additional tax revenue, they will likely require a large increase in state education aid to help close their spending gaps and performance gaps.

It remains important that school districts improve their efficiency, because increasing school funding is not a cure-all. Low efficiency in a district undoubtedly hurts student performance, even if school spending is sufficient for covering the predicted cost, which in this report is calculated mostly at the assumed average efficiency level. School districts and the state, therefore, should work together to determine the best ways to teach students and the most efficient ways to run schools. Only the combination of equitable and adequate spending and high efficiency will ensure that all Connecticut public school districts will reach the common student performance target. 


\section{References}

Connecticut School Finance Project (CSFP). 2018a. “CCJEF v. Rell (2018) (CT Supreme Court Decision)." New Haven, $\mathrm{CT}$ : Connecticut School Finance Project.

Connecticut School Finance Project (CSFP). 2018b. "FY 2019 Budget Changes to School Finance." Presentation updated June 1, 2018. New Haven, CT: Connecticut School Finance Project.

Connecticut School Finance Project (CSFP). 2019. "School Finance 101: An Introduction to How Public Schools Are Funded in Connecticut." Presentation updated March 21, 2019. New Haven, CT: Connecticut School Finance Project.

Connecticut State Department of Education. 2006. "District Reference Groups." Hartford, CT: Connecticut State Department of Education.

Duncombe, William. 2006. "Responding to the Charge of Alchemy: Strategies for Evaluating the Reliability and Validity of Costing-out Research." Journal of Education Finance 32(2): 137-169.

Duncombe, William, and John Yinger. 2005. "How Much More Does a Disadvantaged Student Cost?" Economics of Education Review 24(5): 513-532.

Duncombe, William, and John Yinger. 2011. "Are Education Cost Functions Ready for Prime Time? An Examination of Their Validity and Reliability." Peabody Journal of Education 86(1): 28-57.

Imazeki, Jennifer, and Andrew Reschovsky. 2006. "Does No Child Left Behind Place a Fiscal Burden on States? Evidence from Texas." Education Finance and Policy 1(2): 217-246.

Moran, John D., Marybeth Sullivan, Sarah Bourne, and Alan Shepard. 2016. "Education Cost Sharing Grants." Research Report 2016-R-0167. Hartford, CT: Office of Fiscal Analysis and Office of Legislative Research.

Sullivan, Marybeth. 2018. "Education Cost Sharing Grant Formula." Issue Brief 2018-R-0295. Hartford, CT: Office of Legislative Research.

Wetzler, Lauren A. 2004. "Buying Equality: How School Finance Reform and Desegregation Came to Compete in Connecticut." Yale Law \& Policy Review 22(2): 481-524.

Zhao, Bo. 2020. "Estimating the Cost Function of Connecticut Public K-12 Education: Implications for Inequity and Inadequacy in School Spending." Research Department Working Papers. Boston, MA: Federal Reserve Bank of Boston. 


\section{Notes}




\section{Notes}




\section{Notes}




\section{About the Authors}

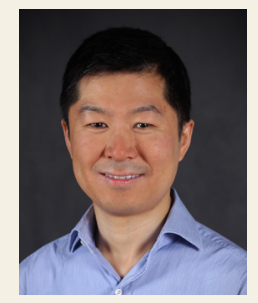

Bo Zhao is a senior economist in the New England Public Policy Center at the Federal Reserve Bank of Boston. He specializes in public finance and urban and regional economics. His work mostly has focused on state and local fiscal issues, including public higher education, fiscal transparency, local fiscal disparities, state aid distribution formulas, rainy day funds, local-option taxes, and public pensions. His articles have appeared in the Journal of Urban Economics, the National Tax Journal, the Journal of Policy Analysis and Management, Regional Science and Urban Economics, and Public Finance Review, among other academic journals. He served on the Municipal Aid Subcommittee of the Municipal Finance Task Force in Massachusetts in 2006 and 2007. Zhao earned his PhD in economics and MS in applied statistics from Syracuse University. His email address is bo.zhao@bos.frb.org.

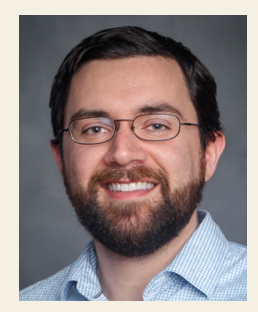

Nicholas Chiumenti is a policy analyst with the New England Public Policy Center in the research department at the Federal Reserve Bank of Boston. His research interests include homelessness prevention and affordable housing policy. Chiumenti holds a Master of Public Policy degree from the John Hopkins University Bloomberg School of Public Health and a BA in international relations from Boston University. Prior to joining the Bank, he worked for the US Department of Commerce Economics and Statistics Administration and was a mayoral fellow for the City of Baltimore. His email is nick.chiumenti@bos.frb.org.

\section{Acknowledgments}

The authors thank Jeff Thompson and the School and State Finance Project for helpful comments and Lan Ha for excellent research assistance. 


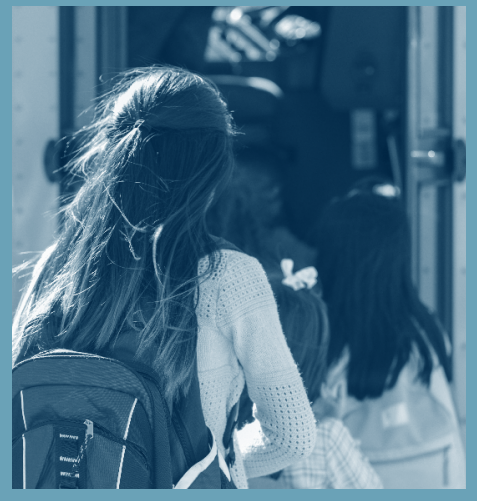

New England Public Policy Center Federal Reserve Bank of Boston 600 Atlantic Avenue

Boston, MA 02210

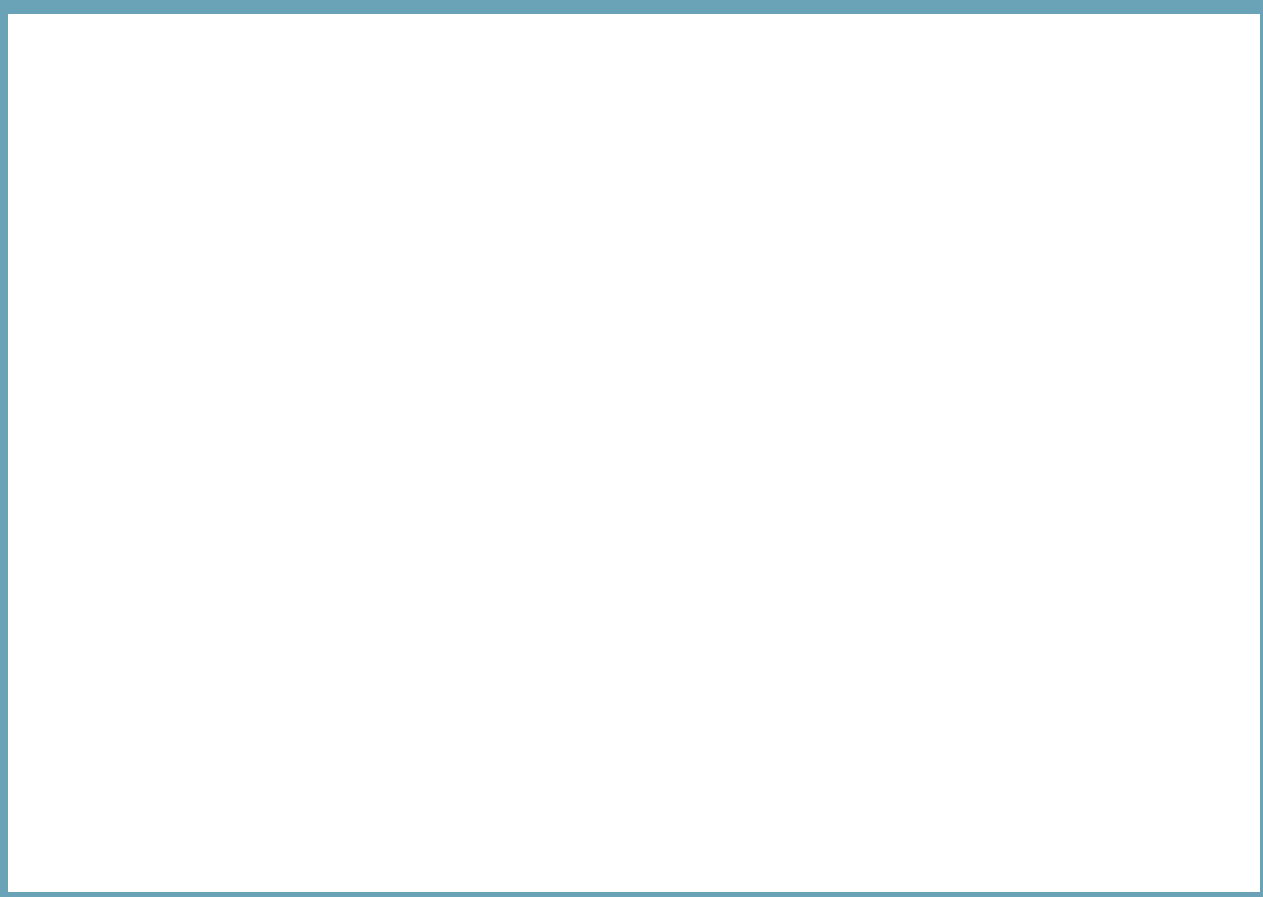

The New England Public Policy Center was established by the Federal Reserve Bank of Boston in 2005. The Boston Fed has provided support to the public policy community of New England for many years; NEPPC institutionalizes and expands on this tradition. The Center's mission is to promote better public policy in New England by conducting and disseminating objective, high-quality research and analysis of strategically identified regional economic and policy issues. When appropriate, the Center works with regional and Bank partners to advance identified policy options.

You can learn more about the Center by contacting us or visiting our website:

New England Public Policy Center

Federal Reserve Bank of Boston

Phone: (617) 973-4257

E-mail: neppc@bos.frb.org

Web: http://www.bostonfed.org/neppc 